\title{
Characterization of Microorganisms Isolated from Petroleum Hydrocarbon Polluted Soil
}

\author{
Adriana CRISTE ${ }^{*}$, Tabita HENȚ ${ }^{1}$, Mihaela GIUBURUNCA ${ }^{1}$, Marius ZĂHAN ${ }^{1}$, Monica NISTE ${ }^{2}$, Nicodim \\ FIT $^{3}$, Mihai MITREA ${ }^{4}$ \\ ${ }^{1}$ Faculty of Animal Science and Biotechnologies, University of Agricultural Sciences and Veterinary \\ Medicine, 400372 Cluj-Napoca, Mănăștur Street 3-5, Romania \\ ${ }^{2}$ Faculty of Agriculture, University of Agricultural Sciences and Veterinary Medicine, 400372 Cluj- \\ Napoca, Mănăştur Street 3-5, Romania \\ ${ }^{3}$ Faculty of Veterinary Medicine, University of Agricultural Sciences and Veterinary Medicine, 400372 Cluj- \\ Napoca, Mănăştur Street 3-5, Romania \\ ${ }^{4}$ Chimgrup SRL, 417565, Suncuius, Romania \\ *Corresponding authors, e-mail: adriana.criste@usamvcluj.ro
}

Bulletin UASVM Animal Science and Biotechnologies 73(1)/ 2016

Print ISSN 1843-5262; Electronic ISSN 1843-536X

DOI:10.15835/buasvmcn-asb: 11648

\begin{abstract}
Bioremediation has received a great deal of attention, and bacteria isolated from polluted soil can be used in that process. In this study, we performed an evaluation of the physiological groups of microorganisms from soil contaminated with petroleum. Bacterial strains were isolated from contaminated soil using the selective enrichment technique. Minimal Salt Media was used for serial dilutions to determine viable cell count. The number of total viable cells and different types of microorganisms in the original sample was determined by serial dilution, agar plating procedure using selective media. The plates were incubated at $30^{\circ} \mathrm{C}$ for $24-72$ hours. Distinct colonies growing on each plate were selected, and stored at freezing temperatures. The bacterial colonies were then identified by Gram staining and biochemical tests. Following our research, it was observed that although the total microbial load of soil is relatively close in value, there are differences regarding the physiological group of microorganisms. In the oil contaminated soil sample the largest group of microorganisms was the nitrous nitrifying bacteria followed by nitrate bacteria. All bacterial strains that were isolated from soil samples contaminated with hydrocarbons but also the Pseudomonas putida and Bacillus subtillis strains can use diesel fuel as a food source. With the increase of diesel fuel concentration from culture medium, the majority of the bacterial strains that were used in our experiments showed an increased value of absorbance. This fact suggests that these strains can be used in bioremediation processes.
\end{abstract}

Keywords: bioremediation, hydrocarbons, polluted soil

\section{INTRODUCTION}

Soil microorganisms include species belonging to three groups: Bacteria, Archaea and Eucarya. Bacteria and fungi are the most abundant groups in soil in terms of number and biomass (Olukunle, 2013).

Numerous bacteria, fungi and algae have been isolated for the breakdown of aromatic hydrocarbons as carbon and energy sources in various studies (Cerniglia, 1992; Lal et al., 2004; Pathak et al. 2008).
Environmental pollution by petroleum hydrocarbons has become a global environmental problem (Adegbola, 2014). Bioremediation of pollutants using the microorganism's ability to degrade these substances includes natural attenuation, which can be enhanced with engineering techniques such as the addition of selected microorganisms or biostimulation (when nutrients are added).

There have been numerous studies regarding the degradation of environmental pollutants using 
bacteria. Some bacteria are known for the fact that they consume only hydrocarbons (Yakimov et al., 2007). Bacteria that are able to degrade hydrocarbons are called hydrocarbon degrading bacteria. The biodegradation of hydrocarbons can be done aerobically and anaerobically, using bacteria such as Pseudomonas and Brevibacillus isolated from soil that was contaminated with petroleum (Grishchenkov et al., 2000).

While many bacteria are capable of metabolising organic pollutants, a single microorganism does not have the enzymatic capacity to degrade all or the majority of the organic constituents from a contaminated soil, which is why usually bacteria communities belonging to several genera are involved (Fritsche and Hofrichter 2005).

The microorganisms that are used in bioremediation are mostly indigenous; however, microorganisms that are isolated from elsewhere and inoculated on contaminated soils can also be used. The final products can be carbon dioxide, water, and simpler compounds which do not affect the environment (Shivendra, 2014).

Both aerobic and anaerobic bacteria are capable to convert the polychlorinated biphenyls (PCB). Research on aerobic bacteria isolated from soil focused on Gram negative lines belonging to Pseudomonas, Burkholderia, Ralstonia, Achromobacter, Sphingomonas and Comamonas genera (Taguchi et al., 2001).

Pseudomonas putida is a microorganism that has a major role in carbon decomposition. Some tests showed that P. putida can decompose all aromatic or aliphatic hydrocarbons. The only substances that cannot be decomposed are teflon, polystyrene and organic compounds that contain a single hydrogen atom (Palleroni, 1992). It was observed that Bacillus subtillis strain BS526 completely degrades acenaphthene, anthracene and benzofluoranthene and can reduce the concentration of naphthalene, indenopyrene (Bayoumi, 2009), but also toluene (Piskonen et al., 2008).

The aim of this study is to characterise the microflora present in hydrocarbon polluted soil in comparison with unpolluted soil and also to isolate and characterise specific microorganisms capable of degrading hydrocarbons. In this regard, it was necessary to determine the physiological groups of microorganism and also the number of microorganisms from Pseudomonas genus, which is recognized for its capacity in the bioremediation process.

\section{MATERIAL AND METHODS}

Biological material: A comprehensive study was conducted for quantitative and qualitative characterisation of the distribution of heterotrophic bacteria in polluted and unpolluted soils. Samples were taken from 2 different places, and each of them was a homogeneous mixture of soil. Work samples were as follows: SM control sample, which was harvested from an area without hydrocarbon pollution; PC - sample with contaminated soil- soil contaminated with hydrocarbons, which was harvested from the site Suplacu Barcau, an area that is recognized for massive petroleum contamination.

Culture media: In order to characterize the microflora of the analysed soil, it was necessary to use special media for isolation and identification. Total aerobic microflora was determinated on solid media for aerobic bacteria. The utilised medium had the following composition: soil extract 750 $\mathrm{mL}$; yeast extract $0.75 \mathrm{~g}$; agar $18 \mathrm{~g}$; distilled water $250 \mathrm{~mL}$. Soil extract was made from $100 \mathrm{~g}$ soil and $100 \mathrm{~mL}$ water. The mixture was autoclaved, and after this step the extract was separated by centrifugation. This was followed by filtering and again by autoclaving.

Determination of the number of aerobic nitrogen microorganisms was done by using a media which did not contain combined nitrogen. The composition was the following: standard saline solution $50 \mathrm{~mL}$; mannitol $10 \mathrm{~g}$; soil extract $10 \mathrm{ml}$; trace elements solution $1 \mathrm{~mL} ; \mathrm{CaCO}_{3} 0.5 \mathrm{~g}$; distilled water $950 \mathrm{~mL}$; agar $15 \mathrm{~g}$. Standard saline solution was obtained from: $\mathrm{K} \mathrm{HPO}_{4} 5 \mathrm{~g} ; \mathrm{NaCl}_{2} 5 \mathrm{~g}$; $\mathrm{MgSO}_{4} .7 \mathrm{H}_{2} \mathrm{O}_{2} 5 \mathrm{~g} ; \mathrm{Fe}_{2}\left(\mathrm{SO}_{4}\right)_{3} 0.5 \mathrm{~g} ; \mathrm{MnSO}_{4}^{4} 0.5 \mathrm{~g}$.

Ammonifying microorganisms carried out the mineralization of aminic acids, peptides and other organic substances with nitrogen to $\mathrm{NH}_{3^{\prime}} \mathrm{CO}_{2}$ and $\mathrm{H}_{2} \mathrm{O}$. In order to isolate these bacteria, a saline medium with the following composition was used: Standard salt solution $50 \mathrm{~mL}$; trace elements solution $1 \mathrm{~mL}$; Distilled water $950 \mathrm{~mL}$; agar 15 g. To develop nitric bacteria, a medium was used which contained: standard saline solution $50 \mathrm{~mL}$; $\mathrm{SO}_{4}\left(\mathrm{NH}_{4}\right)_{2} 0.5 \mathrm{~g} ; \mathrm{CaCO}_{3} 1 \mathrm{~g}$; distilled water 950 $\mathrm{mL}$; agar $15 \mathrm{~g}$. Nitrogen was supplied as sodium nitrite $\mathrm{NO}_{2} \mathrm{Na}$ for nitrous bacteria growing. The 
culture medium for these bacteria consisted of: standard saline solution $50 \mathrm{~mL} ; \mathrm{NaNO}_{2} 1 \mathrm{~g} ; \mathrm{CaCO}_{3} 1$ g; distilled water $950 \mathrm{~mL}$; agar $15 \mathrm{~g}$. The presence of nitrites and nitrates was tested with a reagent of sulfur diphenylamine, and for nitrates in the presence of urea in sulfuric medium. The number of microorganisms that are capable to develop denitrification in soil was investigated by diapering of nitrates in terms of time, using a medium in which the nitrogen is in the form of nitrate $\left(\mathrm{NO}_{\mathrm{K}}\right)$, with the following composition: standard saline solution $50 \mathrm{~mL}$; $\mathrm{NO}_{3} \mathrm{~K} 2 \mathrm{~g}$; glucose $10 \mathrm{~mL}$; $\mathrm{CO}_{3} \mathrm{Ca} 5 \mathrm{~g}$; trace elements solution $1 \mathrm{~mL}$; Distilled water 950 $\mathrm{mL}$; Agar $15 \mathrm{~g}$. GSP agar (Merck) is a medium which allows isolation and identification of species and genera Pseudomonas and Aeromonas. Centrimide agar (Merck) is a solid culture medium which is used in selective isolation of P. aeruginosa.

\section{Work technique}

Determination of total and special microflora: In order to analyse the microorganisms from the soil samples, some special culture media were utilised. These media allowed qualitative and quantitative appreciation of physiological groups of bacteria in the analysed samples. To achieve inoculation, it was necessary to use decimal dilutions. From these dilutions $1 \mathrm{ml}$ was taken which was further used for the inoculation of special media. From each dilution three plates were seeded (dilutions: $10^{-4}, 10^{-6}$ and $10^{-8}$ ). Seeding in depth method was used for isolation of bacterial colonies. The assessment of total aerobic microflora was made from the plates where a number of 30- 300 colonies appeared, and the average of three plates was corrected by the dilution factor in order to obtain the CFU number (CFU/g soil). All samples were incubated at $30^{\circ} \mathrm{C}$. Reading of the results was differentiated according to the group of microorganisms that were investigated. Total microflora was read after 3 and 7 days of incubation. In order to count the colonies of bacteria, fungi, actinomycetes, readings were made 5 and 7 days after incubation. Ammonifying and denitrifying microflora was read at 3 and 7 days after inoculation. Determination of nitrite and nitrate bacteria was made after 20 days from incubation.

Morphological characterization of bacterial strains with an expected hydrocarbon degradation activity: Bacterial strains were passed from the isolation medium in order to obtain pure cultures, incubated at $37^{\circ} \mathrm{C}$ for 24 h. These cultures were morphologically and tinctorially characterised using Gram staining technique.

Examination of the biochemical characters using API tests: To reduce the working time in order to highlight the biochemical characteristics of bacterial strains, API20 NE and API20 A galleries were used.

Testing of hydrocarbon biodegradation capacity: In order to test the capacity of bacterial strains to degrade the hydrocarbons medium MSM was used. The carbon source was diesel fuel. $5 \mathrm{~mL}$ of MSM culture medium was poured into sterile tubes, different concentration of hydrocarbons were added $(10,25,50,100 \mu \mathrm{l})$, and after that the inoculation was made with $100 \mu \mathrm{l}$ of culture from liquid culture medium. To interpret the results, control samples were needed for each strain of bacteria: $5 \mathrm{~mL}$ of culture medium and $100 \mu \mathrm{l}$ of bacterial culture were prepared according to the same protocol. The test tubes were kept for $48 \mathrm{~h}$ at room temperature with continuous shacking at $120 \mathrm{rpm}$. The results were interpreted using a UV spectrophotometer. Readings were taken at 600 $\mathrm{nm}$ wave length. The resulting values represented the absorbance due to the development of microorganisms.

\section{RESULTS AND DISCUSSIONS \\ Evaluation of physiological groups of microorganisms from soil}

Involved in the bioremediation process with a special importance are different active microorganisms (bacteria, including cyanobacteria and actinomycetes, yeasts and filamentous fungi) which are widespread in nature, and which degrade various compounds. Soil contamination with petroleum increases the total microbial population, but greatly restricts the number of species, favoring only the development of microorganisms that can degrade it in simple compounds.

Perhaps more important than the total quantity of microorganisms is their activity and the relationship between several physiological groups of bacteria. Identification of these special conditions may facilitate the biological characterisation of samples, allowing us to obtain some information about the transformation process. 
Tab. 1.Evaluation of total microflora and of the physiological group of microorganisms isolated from soil samples

\begin{tabular}{ccc}
\hline Microorganisms group & $\begin{array}{c}\text { Contaminated soils } \\
\text { CFUx } 10^{4}\end{array}$ & $\begin{array}{c}\text { Control sample } \\
\text { CFUx } 10^{4}\end{array}$ \\
\hline Total aerobic microflora & 57 & 51 \\
Nitrogen fixing microflora & 9 & 19 \\
Ammonifying microflora & 102 & 209 \\
Nitrous microflora & 278 & 127 \\
Nitrate microflora & 179 & 128 \\
Denitrifying microflora & 6 & 43 \\
Pseudomonas (Cetremide agar) & 232 & 119 \\
Pseudomonas (GSP agar) & 3 & 97 \\
\hline
\end{tabular}

Quantitative assessment was performed using solid nutritive media, which allow the evaluation of $\mathrm{CFU} / \mathrm{g}$ soil and observation of the colony morphology. Also, the solid nutritive media permit to exploit the colonies through passing and through morphological and biochemical characterisation of the isolated strains.

\section{Determination of total aerobic microflora}

In soil, all major taxonomic groups have been identified; it is estimated that there are at least 13,000 of bacterial species.

Determination of total aerobic microflora represents a quantitative assessment of soil microorganism which are capable of developing under aerobic conditions at a temperature of 25$30^{\circ} \mathrm{C}$. This charge usually depends on the source of nutrients from soil, and depending on these the soil biodiversity may vary. Thus, the total aerobic load is $57 \times 10^{4}$ in contaminated soil samples, which is higher but closed to that observed in the control sample $\left(51 \times 10^{4}\right)$. These results show that, overall, the soil samples have a closed in value of microbial charge, but the share of certain physiological groups of microorganism may be different.

\section{Determination of atmospheric nitrogen fixing microflora}

Nitrogen gas from the atmosphere under the action of nitrogen fixing microorganisms gets in the soil in an organic form. In order to calculate the total number of aerobic atmospheric nitrogen fixing microorganisms, a liquid medium which does not contain combined nitrogen was seeded with soil dilutions. Following the analysis performed to determine nitrogen fixing microflora, it has been observed that the load in the sample of contaminated soil was $9 \times 10^{4}$, which is less than that observed in the control sample, in which the load was $19 \times 10^{4}$.

\section{Determination of ammonifying microflora}

Ammonifying microorganisms perform the mineralisation of aminic acids, peptides and other organic substances to $\mathrm{NH}_{3}, \mathrm{CO}_{2}$ and $\mathrm{H}_{2} \mathrm{O}$. The results showed that the ammonifying load of control sample was $209 \times 10^{4}$, while in the contaminated soil sample the load had a value of $109 \times 10^{4}$ microorganisms, half of the control sample value. We can deduce that the pollutant present in the contaminated soil sample inhibits the growth of bacteria from this category.

\section{Determination of nitrifying microflora}

Nitrification represents the process by which ammonia is first oxidised to nitrite by nitrobacteria, and in the next step, the nitrobacteria will oxidise the nitrite to nitrate. In this category of nitrification microorganism, depending on the source of nitrogen, are involved two groups: nitrous bacteria and nitric bacteria. To determine the nitrous bacteria, a medium where the nitrogen source was $\mathrm{SO}_{4}\left(\mathrm{NH}_{4}\right)_{2}$ was used; to determine nitric bacteria, the source was $\mathrm{NO}_{2} \mathrm{Na}$.

The load of nitrous microflora was $127 \times 10^{4}$ microorganisms for the control sample, but this value was doubled in the contaminated soil reaching a value of $278 \times 10^{4}$ microorganisms. This can be explained by the fact that these microorganisms decompose and use the pollutant from soil as food. The results for determination of nitric bacteria showed that the contaminated soil had a value of $179 \times 10^{4}$ microorganisms, which is higher than that observed in the control sample (128x $10^{4}$ microorganisms). 
Denitrification is the last phase of the process, where a part of nitrate is lost by reducing it by microorganisms to nitrites, ammonia and nitrogen gas, which will return in the biological circuit. The number of microorganisms capable of producing denitrification in the soil is investigated by monitoring the disappearance of nitrates to time. Dilutions of soil suspension are seeded in a medium where nitrogen is in the form of nitrate $\left(\mathrm{NO}_{3} \mathrm{~K}\right)$.

Following the analysis performed to determine the denitrifying microflora it was observed that the control sample had a load of $43 \times 10^{4}$ microorganisms, and the contaminated soil sample had $6 \times 10^{4}$ microorganisms. This microorganism category has a lower share from the total microflora, but there is a difference between the two samples. Also, the development of some fungi in addition of the specific bacterial microflora was observed in this medium.

\section{Determination of bacteria from Pseudomonas genus}

Pseudomonas sp. is a bacterial genus which is commonly found in soil but some strains have a major importance in bioremediation. The microorganisms from this genus are capable of utilising hydrocarbons as carbon source, therefore explaining the fact that polluted soils have a larger load of these microorganisms.

Centrimede Agar (Merck) is a culture medium that favors the development of these microorganisms, which is why it was used to determine the total number of bacteria from Pseudomonas genus. As expected, the soil load was different between the two samples. While in control sample the load had a value of $119 \times 10^{4}$ microorganisms, the contaminated soil sample had a value of $232 \times 10^{4}$ microorganisms, which is almost double the value. This can be attributed to the fact that Pseudomonas sp. can decompose and utilise the pollutant from soil as food source.

GSP (Merck) medium is a culture medium which is utilised to isolate the microorganisms from Pseudomonas genus and to identify the Pseudomonas aeruginosa species. While in the total microflora from soil we can find representatives of Pseudomonas aeruginosa, in soils contaminated with hydrocarbons a development of other species, such as Pseudomonas putida, Pseudomonas liquefaciens, Pseudomonas striata, Pseudomonas borbopolis can be noticed. Of particular importance in these soils contaminated with hydrocarbons is Pseudomonas putida.Such determination using GSP medium allows us to make an assessment of specific microflora, and to distinguish between the total number of bacteria from Pseudomonas genus and the number of Pseudomonas aeruginosa species.

Following the analysis, it was noted that the microbial load had a lower value when Centrimede Agar medium was used, and also had a lower value for the sample with contaminated soil. The contaminated soil sample had a value of $3 \times 10^{4}$ microorganisms, which is lower in comparison with the control sample, which had a value of $97 \times 10^{4}$ microorganisms. This demonstrates that the bacteria from Pseudomonas sp. developed on Cetremide Agar are mainly bacteria which utilise hydrocarbons as carbon source, while the microflora from the control sample was represented generally by Pseudomonas aeruginosa. This species is commonly encountered in unpolluted soils.

Total aerobic microflora may not contain all the microorganisms from soil because the different physiological groups of microorganisms need specific nutrients that are covered by special culture media. However, to determine the total microflora it is an important indicator in assessing soil biodiversity. Thus, it was observed that although the total load of microorganisms from soil is relatively close in value, there are differences regarding the physiological groups. While in the control sample there was a balance between the physiological groups of microorganisms, with an important share of ammonifying microorganisms but also of nitification microorganisms, in the contaminated sample the share was slightly different. Nitrous nitrification bacteria had the highest share, followed by nitrite nitrification bacteria and by ammonifying bacteria.

A major difference was observed in the total number of Pseudomonas sp. from the analysed samples. In soil, after the contamination process, the bacteria degrading hydrocarbons represented $50 \%$ of the total micro-population. Bacteria from Pseudomonas genus can represent 66\% of the total. Involved in the bioremediation process are some species such as: Pseudomonas putida, Pseudomonas aeruginosa, Pseudomonas liquefaciens, Pseudomonas striata, Pseudomonas borbopolis. 
Isolation and identification of some strains from hydrocarbon polluted soils

In general, biodegradation of petroleum hydrocarbons represents degradation of some complex organic compounds in simple compounds. This process is done in several stages and it is not only the result of a specific microorganism. Usually, several strains of microorganisms act synergistically. The microorganisms that are involved in biological remediation of contaminated soils (with hydrocarbons) have a particular importance because they can be used in remediation.

The aim of this experiment was to isolate bacterial strains that can be used in bioremediation of hydrocarbon contaminated soils. For this purpose, several colonies with different cultural characteristics were passed and characterised from a morphological and biochemical standpoint:

Morphological and biochemical characterisation of isolated strains

Both Gram positive and negative bacterial genera were isolated and assumed to have a common pattern of tolerance and degradation of petroleum (Islam et al.,, 2013). After this experiment, we could appreciate that the microflora involved in the bioremediation process is a specific one. To characterise the type of microorganisms that are present in the total aerobic microflora, the colonies developed on culture media were passed and subsequently characterized biochemically and morphologically. We managed to isolate 18 strains that can have potential role in bioremediation. Morphologically,

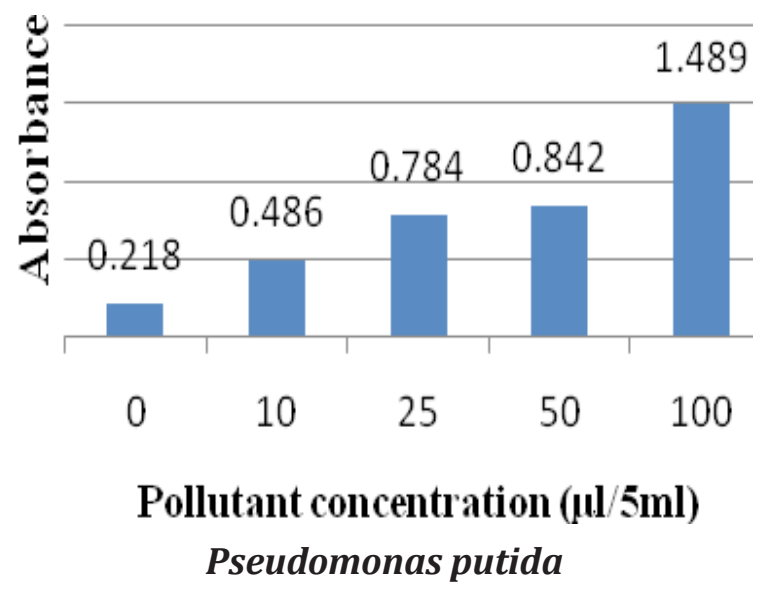

it was observed that these strains belong mainly to two microbial genera, namely Pseudomonas and Bacillus. Of these, four strains belong to Pseudomonas sp. and 8 strains to Bacillus, and along with Pseudomonas putida F1 and Bacillus subtillis they will be used in bioremediation tests.

Research on diesel biodegradation capacity of the isolated strains

The process of biodegradation of petroleum hydrocarbons is a slow natural process. This process is based, on the one hand, on the use of microorganisms in soil, which adapted to the contaminant, and on the other hand on the incorporation in the soil of indigenous microorganisms. The following figures present the results of the bioremediation tests performed with the bacterial strains isolated from soil and with Pseudomonas putida and Bacillus subtillis. The values of absorbance along with the diesel concentration from culture medium are represented.

The isolated strains of Pseudomonas 1 and 2 demonstrate the influence of the amount of pollutant on bacterial biomass concentration; as there is more diesel in the medium, the amount of bacteria increases due to a greater quantity of substance that can be decomposed by bacteria and after that used as food supply. A linear relationship can be observed between the increase in concentration of hydrocarbons in the medium and the concentration of bacterial biomass after $48 \mathrm{~h}$ of incubation. In the case of Pseudomonas 3 strain, this relationship is very clear, given the relatively small amount of the bacterial biomass concentration

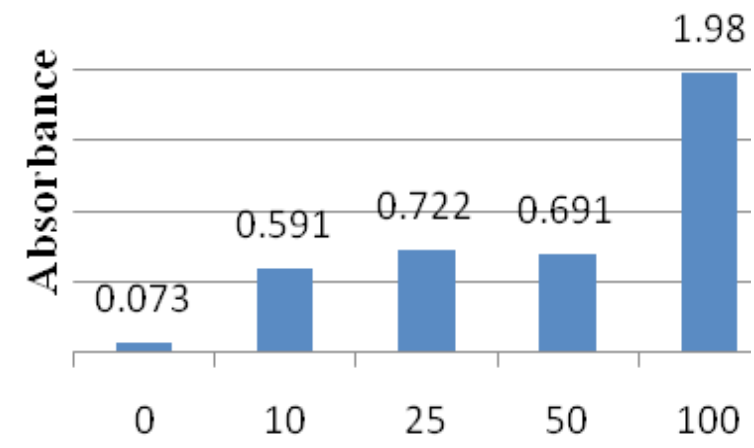

\section{Pollutant concentration ( $\mathrm{\mu l} / \mathbf{5 m l}$ ) Bacillus subtililis}

Fig.1. Absorbance observed in biodegradation of diesel Pseudomonas putida F1 and Bacillus subtillis from strains collection 
from the control sample in comparison with the test sample where we introduced the highest concentration of contaminant.

All four bacterial strains belonging to Pseudomonas genus that were isolated from soil samples contaminated with hydrocarbons showed positive effects on degradation of diesel from the culture medium highlighting in particular the bacterial strain Pseudomonas 3, which has the highest value of absorbance $2074 \mathrm{~cm}^{-1}$, when the concentration of diesel from the culture medium was $100 \mu \mathrm{l}$. The control sample had the lowest absorbance $\left(0.105 \mathrm{~cm}^{-1}\right)$ because of the lack of pollution source in the culture medium.

All four bacterial strains belonging to Pseudomonas genus that were isolated from soil samples contaminated with hydrocarbons showed the same pattern as that observed in Pseudomonas putida.

For Bacillus 1 strain, the contaminant concentration of 10,25 and $50 \mu$ l had similar effects upon the biomass concentration, which

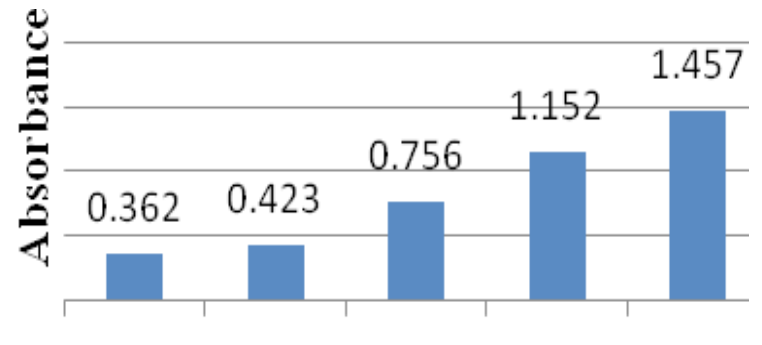

$\begin{array}{lllll}0 & 10 & 25 & 50 & 100\end{array}$

Pollutant concentration ( $\mathrm{\mu l} / \mathbf{5 m l})$ Pseudomonas 1

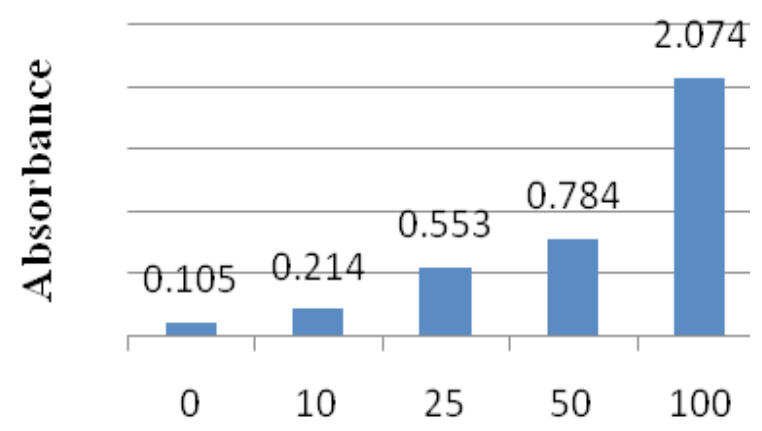

Pollutant concentration ( $\mu \mathrm{l} / 5 \mathrm{ml})$ Pseudomonas 3 had approximately equal values $\left(0.542 \mathrm{~cm}^{-1}\right.$, $0.564 \mathrm{~cm}^{-1}, 0.687 \mathrm{~cm}^{-1}$ ), but when the concentration of the contaminant was doubled to $100 \mu \mathrm{l}$, the bacteria showed an increase (the value of the absorbance was $1.568 \mathrm{~cm}^{-1}$ ), which demonstrates the decomposing of hydrocarbons from diesel and their use as food source.

In the case of Bacillus 3 and Bacillus 4 strains, the same effect can be observed on the growth of the concentration of bacterial biomass, the optimum value of the concentration of pollutant being $100 \mu$ l for the two strains that are represented in the graph above. The absorbance for Bacillus 3 strain had a value of $2.348 \mathrm{~cm}^{-1}$ and for Bacillus 4 strain the value was $2.146 \mathrm{~cm}^{-1}$. These values were higher than the value ovserved in Bacillus subtillis strain.

For Bacillus 5 strain, which was isolated from contaminated soil, the concentration of pollutant $(10,25$ and $50 \mu \mathrm{l})$ had positive effects upon the bacterial biomass concentration. Bacillus 6 strain showed the influence of pollutant concentration

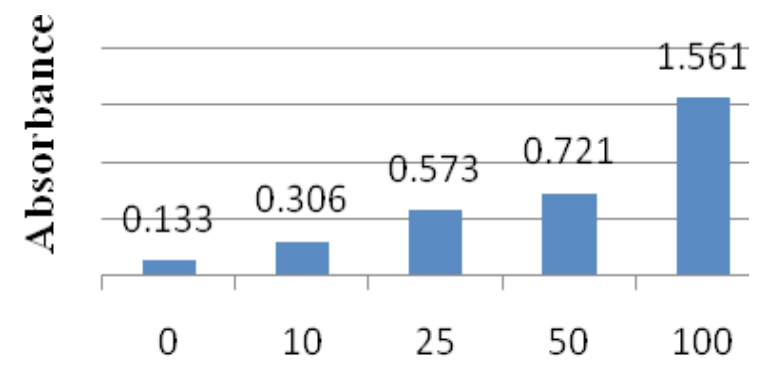

Pollutant concentration $(\mu \mathrm{l} / 5 \mathrm{ml})$

Pseudomonas 2

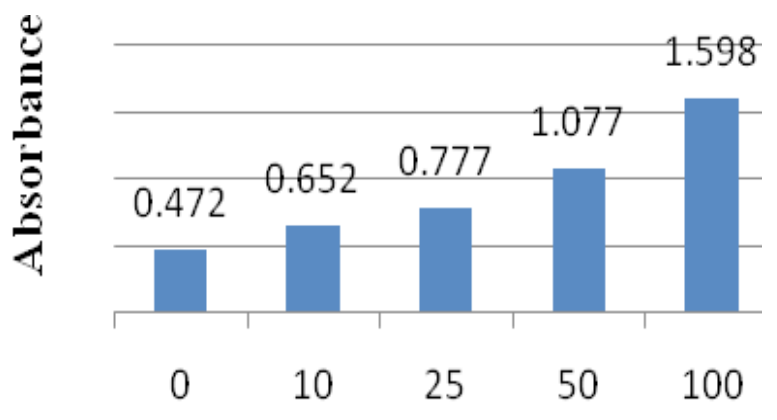

Pollutant concentration $(\mu \mathrm{l} / 5 \mathrm{ml})$

Pseudomonas 4

Fig.2. Absorbance observed in biodegradation of diesel

Bacterial strains Pseudomonas 1 - Pseudomonas 4 represents the strains isolated from hydrocarbon contaminated soil 


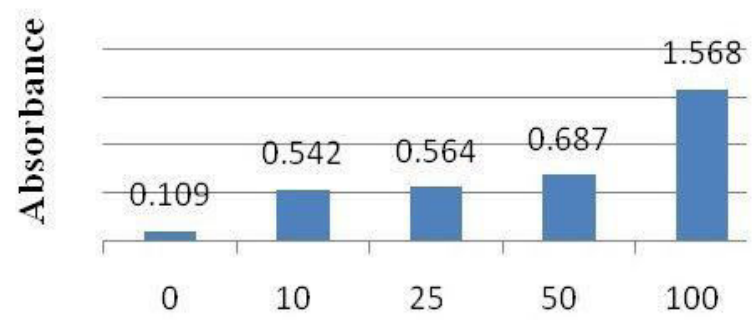

Pollutant concentration $(\mu \mathrm{l} / 5 \mathrm{ml})$

Bacillus 1

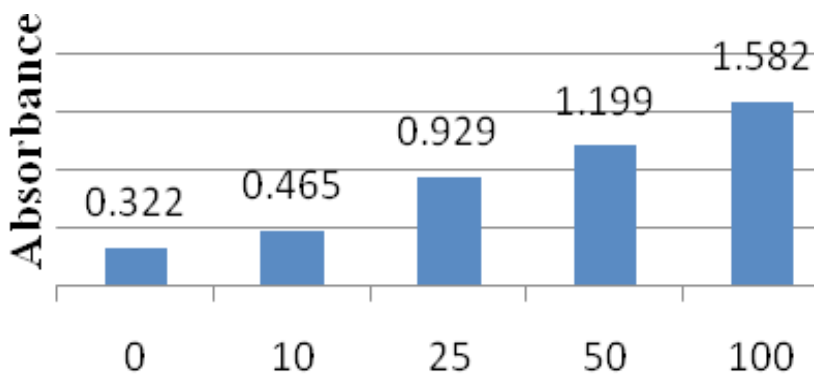

Pollutant concentration $(\mu \mathrm{l} / 5 \mathrm{ml})$

Bacillus 2

2.348

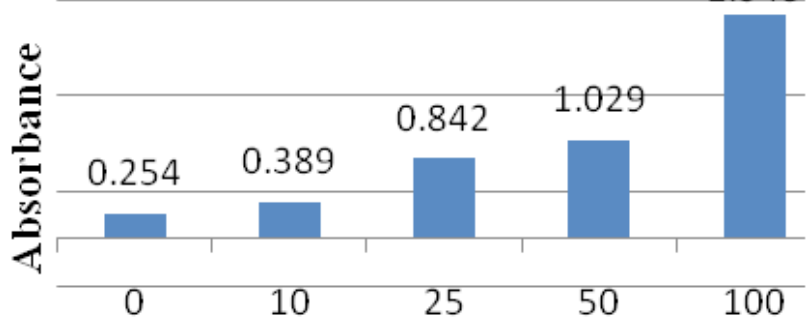

Pollutant concentration $(\mu \mathrm{l} / 5 \mathrm{ml})$

Bacillus 3

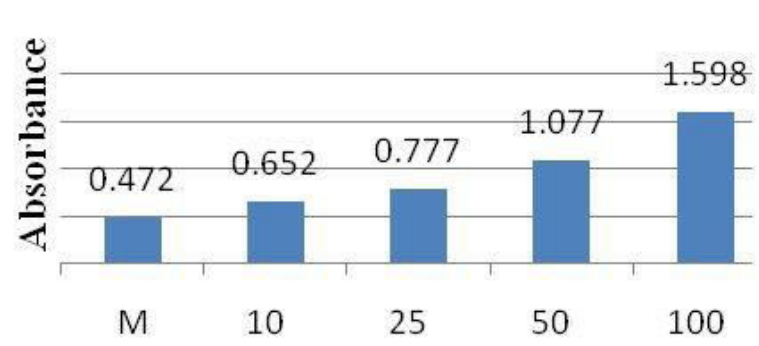

Pollutant concentration $(\mu \mathrm{l} / 5 \mathrm{ml})$

Bacillus 5

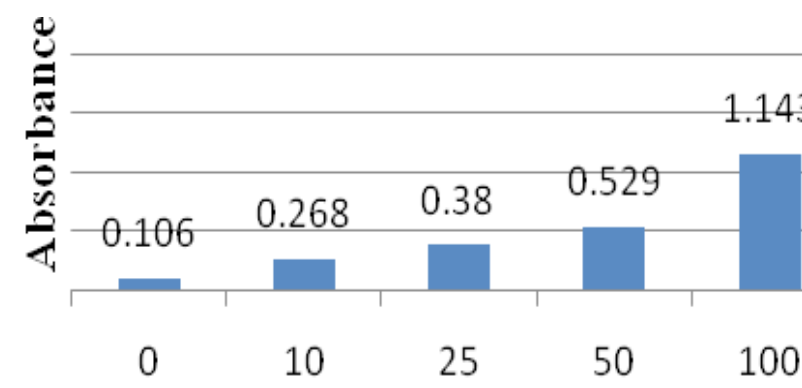

Pollutant concentration $(\mu \mathrm{l} / 5 \mathrm{ml})$

Bacillus 7

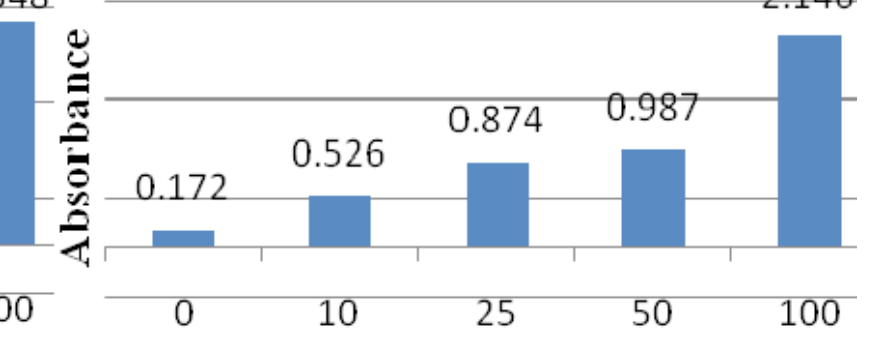

Pollutant concentration $(\mu \mathrm{l} / \mathbf{5 m l})$

Bacillus 4

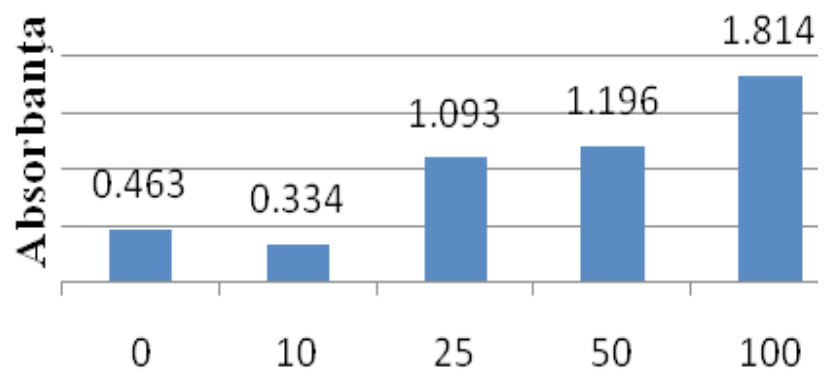

Pollutant concentration ( $(\mu \mathrm{l} / 5 \mathrm{ml})$

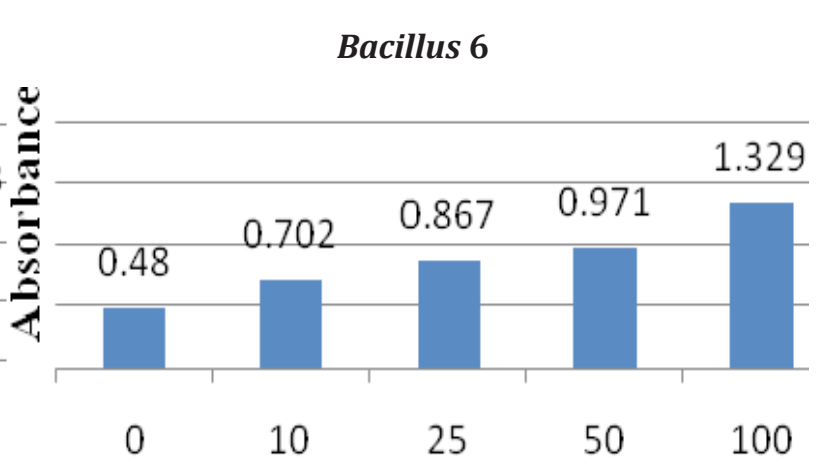

Pollutant concentration ( $\mu 5 / \mathrm{ml})$

Bacillus 8

Fig.3. Absorbance observed in biodegradation of diesel

Bacterial strains: Bacillus1 - Bacillus 8 represent the strains isolated from hydrocarbon contaminated soil 
on absorbance, which increased at 25, 50 and $100 \mu \mathrm{l}$ concentrations, and decreased at $10 \mu \mathrm{l}$ concentration.

From the previously analysed graphs, one can observe the biodegradation of the diesel fuel by the strains of this genus of microorganisms, each of which managed to decompose this soil pollution source. The best concentration at which bacteria decomposed the pollutant was the $100 \mu \mathrm{l}$. Among the isolated strains of Bacillus, the best results were observed at Bacillus 3 strain, where the absorbance had a value of $2.348 \mathrm{~cm}^{-1}$.

Pseudomonas putida strain confirms that the species of this genus are capable of bioremediating the polluted soils through the decomposition of hydrocarbons and their use as food source. The Bacillus subtillis strain yielded satisfactory results for the bioremediation of soils polluted with diesel fuel, the highest values being observed at the highest concentration tested.

\section{CONCLUSIONS}

Following the research on microflora characterisation present in hydrocarbon contaminated soils, and on isolation and characterisation of specific microorganisms that are capable of degrading the hydrocarbons from soil, it was observed that although the total load of soil is relatively close in value, there are differences as regards its physiological groups of microorganisms. In the contaminated soil sample, the highest load of microorganisms was represented by nitrous nitrification bacteria, followed by nitrate nitrification bacteria and ammonifying bacteria.

All bacterial strains isolated from the contaminated soil sample can use the diesel fuel as food source, and these strains can be used in the process of bioremediation of soils contaminated with hydrocarbons of this type. Pseudomonas putida and Bacillus subtillis strains also had positive results in terms of the degradation of diesel fuel from the culture medium and it is used as a food source.

With the increase in concentration of diesel fuel in culture media, the majority of bacterial strains used in our experiments indicated an increase in absorbance, which can explain the fact that these strains can be used in bioremediation processes.
Acknowledgements. This work was supported by a grant of the Romanian national authority for scientific research, CNDIUEFISCDI, project number PN-II- PN-II-PTPCCA-2013-4-1717.

\section{REFERENCES}

1. Adegbola GM, Eniola KIT, Opasola OA (2014). Isolation and identification of indigenous hydrocarbon tolerant bacteria from soil contaminated with used engine oil in Ogbomoso, Nigeria; Advances in App Sci Res, 2014, 5(3):420-422.

2. Bayoumi AR (2009). Bacterial bioremediation of polycyclic aromatic hydrocarbons in heavy oil contaminated soil, J App Sci Res, 5 (2):197-211.

3. Cerniglia CE (1992). Biodegradation of polycyclic aromatic hydrocarbons. In E. Rosenberg (ed.), Microorganisms to combat pollution. Kluwer Academic Publishers, Dordrecht, the Netherlands:351-368.

4. Fritsche $\mathrm{W}$ and Hofrichter M (2005). Aerobic degradation of recalcitrant organic compounds by microorganisms, in environmental biotechnology: Concepts and applications (ed. H.J. Jördening and J. Winter), Wiley-VCH Verlag GmbH \& Co. KGaA, Weinheim, FRG

5. Grishchenkov VG, Townsend RT, McDonald TJ, Autenrieth RL, Bonner JS, Boronin AM. (2000). Degradation of petroleum hydrocarbons by facultative anaerobic bacteria under aerobic and anaerobic conditions. Process Biochem; 35(9):889-896.

6. Islam TH, Ghosh B, Magnet MMH, Fatema K, Akter S (2013). Isolation and identification of petroleum degrading bacteria from oil contaminated soil \& water and assessment of their potentiality in bioremediation. IOSR J Environ Sci, Tox Food Techn 5(2):55-58.

7. Olukunle OF (2013). Characterization of Indigenous Microorganisms Associated with Crude Oil-polluted Soils and Water Using Traditional Techniques. Microb J, 3: 1-11.

8. Lal B, Sharma MP, Bhattacharya D, Krishnan S (2004). Assessment of intra species diversity among strains of Acinobacter baumannii isolated from sites contaminated with petroleum hydrocarbons. Canad J Microb, 50(6): 405-414.

9. Palleroni N (1992). Human-and Animal Pathogenic Pseudomonas, The Prokaryotes Volume III, New York: Springer-Verlag.

10. Pathak H, Jain PK, Jaroli DP, Lowry ML (2008). Degradation of Phenanthrene and Anthracene by Pseudomonas Strain, Isolated From Coastal Area. Bioremediation Journal, 12(2): 111-116.

11. Piskonen R, Nyyssönen M, Itävaara M (2008). Evaluating the biodegradation of aromatic hydrocarbons by monitoring of several functional genes, Biodegradation, 19:883-895

12. Shivendra S, Pathak H (2014). Pseudomonas in Biodegradation; Int. J. Pure App Biosci 2 (1):213-222.

13. Taguchi K, Motoyama M, Kudo T (2001). PCB/biphenyl degradation gene cluster in Rhodococcus rhodochrous 
K37, is different from the well-known bph gene clusters in Rhodococcus sp. P6, RHA1, and TA42. RIKEN Review, 42:23-26
14. Yakimov MM, Timmis KN, Golyshin PN (2007). Obligate oil-degrading marine bacteria. Curr Opin Biotechn, 18(3):257-266. 